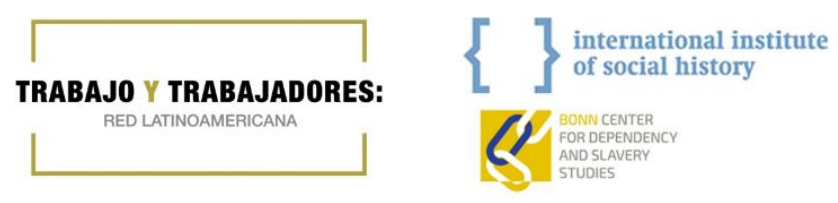

DEBATES AND INTERVENTIONS

\title{
Interview with Karin Hofmeester, First Woman as Director of the Research Department at the IISH
}

\author{
ROSSANA BARRAGÁN \\ International Institute of Social History, The Netherlands \\ rba@iisg.nl
}

The International Institute of Social History has a long history. It was established in 1935 with the Netherlands Economic History Archive (NEHA), with archives of companies and labour organizations and other historical collections. The institution saved documents from all over Europe, collecting, among many other materials, the archives of Marx and Engels, the holdings of the Spanish CNT-FAI, and the important anarchist collection of Max Nettlau, in which Latin America's labour newspapers are particularly relevant. After difficult times during the Second World War, the institute gradually recovered and continued to enlarge its collections.

The Research Department was created under the umbrella of directors Eric Fisher (1984-1993) and Jaap Kloosterman (1993-2008). It received an important boost with the work done by Jan Lucassen, Director of Research, and Marcel van der Linden, editor of the International Review of Social History since 1987. Marcel van der Linden succeeded Jan Lucassen as head of the Research Department between 2001 until 2014. Together, they wrote Prolegomena for a Global Labour History in 1999. At that time, "labour history was confined to white, male, European, or American Industrial workers" (Bosma and Hofmeester, 2018: 3) and their Prolegomena constituted a whole program that guided the research of the IISH.

In 2014, Leo Lucassen (brother of Jan) was appointed as Research Director. In April 2020, he replaced Henk Wals as general director of the IISH and Karin Hofmeester became the new Director of Research. She is the first 
woman appointed to such responsibility after several 33 years working at the institution.

Karin Hofmeester acquired her $\mathrm{PhD}$ at the University of Amsterdam, in 1999, and is Professor of Jewish Culture at Antwerp University. One of her first books was Jewish Workers and the Labour Movement. A Comparative Study of Amsterdam, London and Paris 1870-1914, published in 2004. She specialises in the historical study of diamonds. Together with Marcel van der Linden, she recently edited the Handbook of Global History of Work (Berlin: De Gruyter, 2018). She also wrote several articles and books as co-author and co-editor, with Kristine Moll Murata, Jan Lucassen, among others. She is currently working on her book on Luxury and Labour on Diamonds as Global Commodity, and she is project leader of the Global Collaboratory on the History of Labour Relations in the period 1500-2000.

Rossana Barragán: First, my sincere congratulations for your appointment and we wish you success. You are the first woman to act as Director at the Research Department at the IISH. For a broad audience, this could be strange because the Netherlands is considered, in Latin America, one of the Nordic European countries that had one of the best systems of welfare, education, advanced rights, individual liberties and a clear better situation for women. However, it is particularly striking that you were one of the few women among at least seven senior researchers. Why is gender imbalance still so visible at the IISH? How to explain this situation within an institution considered in general at the vanguard in terms of political positions and its research?

Karin Hofmeester: We have always had women in the research department but it is true that they are still underrepresented amongst the tenured staff. The IISH reflects the general situation in Dutch academia, where women are still underrepresented in top positions and in this regard the Research Department (this is not the case with the Collections Department) is not at the vanguard.

R.B.: Since the Prolegomena of 1999, Global Labour History became the main pillar of the Research Department. This agenda emerged as a response to the classical labour history centred in England and its process of industrialization, even in Marx and Marxist analysis, driven by European history as a model. There was, then, a spatial expansion of labour history but also an expansion in time, in order to consider all kinds of labour. In this context, you were head of the Global Collaboratory on the History of Labour Relations considering a span of time throughout the period 1500-2000. What 
do you think are the main contributions of the IISH to this global labour history?

K.H.: One contribution of the IISH to global labour history is that the idea of embracing all forms of labour, including slave labour, domestic labour, self-employment etcetera is now widely accepted. This 'inclusive' view on labour and labour relations is necessary if you want to get a clear picture of developments in labour worldwide and over a long period of time-the Handbook Global History of Work that Marcel van der Linden and I edited reflects this trend. Next year Jan Lucassen's Work, a Concise History will be published which describes work and labour relations from the period of hunter-gatherers until today in a global perspective - this is really the outcome of our Global Labour History program. The work done by Marcel van der Linden very much helped to set up frameworks for the study of labour, labour organisations and forms of collective action whereas the Collaboratory provides labour historians with data and a taxonomy of labour relations. The IISH has also contributed to global labour history by shaping infrastructure: supporting or participating in networks of labour historians worldwide; giving a master class on Global Labour History, organizing workshops and conferences, offering a platform in its journal, the International Review of Social History.

R.B: The causes and mechanisms underlying social and economic inequality between and within societies are now the research mission of the IISH. Inequality is linked in recent years to contributions made by economists such as Thomas Piketty (Le Capital au XXIe siècle, 2013) and Branko Malinovic (The Haves and the Have-Nots: A Brief and Idiosyncratic History of Global Inequality, 2010; A New Approach for the Age of Globalization, 2016; Capitalism, Alone, The Future of the System that Rules the World, 2019). Both of them raised the issue of wealth inequality and its increase in the last decades and centuries. This means a growing power of the rich, underlining inequality as a feature of a capitalist system that needs to be reformed from the state. Could you, please explain, for the large audience, the slight shift at the Institute from the main topic of global labour relations to this new inequality perspective?

K.H.: This should not be seen as a shift but rather as an extra layer or perspective. Our main research question is now: how is social inequality influenced by global labour relations, what is the relation between unequal access to resources and opportunities (including political rights) and labour relations? We think the debate on social inequality overlooks work and labour relations, in the work of many economists the factor labour is just simply there. Exactly how this labour force is made up, under which type of labour relations people work, who these people are and who earns what under 
which circumstances is not taken into account whereas these are very important questions if we want to address the question of social inequality.

R.B.: In the Research Department, there is somehow a tension among the macro and quantitative approaches that appears always as more unequivocal/undeniable, aligned with institutional economics perspectives, with social history (and Marxist) approaches. How do these viewpoints coexist, and above all, how do they dialogue between them and enrich research at the IISH? What is your leadership on this issue?

K.H.: Apart from the above-mentioned Handbooks and theoretical frameworks the IISH Research Department is also good in thorough historical research of geographical areas; work spaces (plantations, mines, shipyards) and hubs in global commodity chains explicitly placing these case studies in a global context, comparing and connecting mechanisms of allocation and coordination of work we see. At the same time, we want to keep an open eye on the collective and individual action of workers to change their position. If we look at the latest book by Ulbe Bosma, The Making of a Periphery: How Island Southeast Asia Became a Mass Exporter of Labor, we see how his innovative archival research and his use of the methodology of the Collaboratory enabled him to show how in the nineteenth century rural areas in Island Southeast Asia became integrated in the global market in various ways. Existing labour relations were adapted to this integration. This was not one homogenizing process, as scholars like Daron Acemoglu would have it. This is one example of the dialogue between the two approaches that the IISH is good at: we produce case studies that nuance and challenge the "big theories”.

R.B.: Piketty, in his recent book (Capital and Ideology, 2019) is going to the political roots of the "inequality regime" (legal, fiscal, etc.) and to the system of world and colonial domination of western societies, including slave and unfree societies. This reveals a move from an economist's perspective to political economy and global issues of power relationships. Race and gender are, on the other hand, two other candent topics. The consequences of the movement "Black Lives Matter" raised questions on inequality, discrimination and representation all over the world. How is the IISH considering to assume these challenges in order to have a diversity of researchers, to embrace different perspectives and to include those topics into the research program?

K.H.: To start with the latter: when we look at social inequality we explicitly include what Göran Therborn calls existential inequality, i.e. unequal access to various resources caused by discrimination and oppression based on race, gender, sexual identity etc., comparable to Charles Tilly's durable inequality. This perspective will be developed much better if we are in dialogue with a 
diverse group of researchers both inside and outside the IISH. This is already the case in our research on slavery as conducted by Pepijn Brandon, Guno Jones, Nancy Jouwe and Matthias van Rossum (eds), De Slavernij in Oost en West. Het Amsterdam-onderzoek (Amsterdam: Spectrum, 2020) with 38 diverse contributions, with migrant background. This book deals in how people in and around the Amsterdam administration were involved in slave trade and slavery. We also have formulated an explicit policy to actively look for a more diverse IISH staff.

R.B.: It is an important moment for you and your career but also for the institute. What do you think about the challenges you will have in the following years and what could be your own print being a woman as head of the Research Department at the IISH?

K.H.: One of our major challenges in the coming years is to formulate a solid research policy on global labour relations and social inequality and convince research funds of the importance of this topic. We have to develop new research projects on this theme so we can hire talented, young academics with a diverse background to come and work at the IISH or work with us in tight, global networks. We will combine our work on data with text mining projects, combining for example the Taxonomy of Labour Relations developed as part of the Global Collaboratory with insights from the Grammars of Coercion working group of the COST Action "Worlds of Related Coercions in Work" (WORCK). I think we can add to the current world wide societal debate on social inequality and we should share our insights with a wider audience. As a woman heading the Research Department I hope to encourage and inspire other women. 